\title{
Developing a self-learning model based on open-ended questions to increase the students' creativity in calculus
}

\author{
Nurdin Arsyad, Abdul Rahman \& Ansari S. Ahmar
}

Universitas Negeri Makassar

Makassar, Indonesia

\begin{abstract}
This article reports on research that is aimed at developing and producing a self-learning model based on open-ended questions or the PMBST (accronym form Indonesian) model to increase students' creativity in a calculus subject. The main product generated is a book on the PMBST model. It consists of: a) introduction; b) theoretical rationality; c) empirical rationality; d) supporting theories; e) components of the model; f) instructions for the model; and g) bibliography. Furthermore, to assess the quality of this model, the authors used product quality assessment criteria created by Nieveen, which covers hypothetical validity and practicality. The instrument, which is developed for supporting the PMBST model development cover: an assessment sheet of the PMBST model, and a validation format of the PMBST model assessment sheet. The subjects of the PMBST model in this research are Master's programme students in the Mathematics Department at Universitas Negeri Makassar who have finished or are learning the calculus subject. The result of this research is the PMBST model developed with high theoretical rationality as indicated by experts' assessments.
\end{abstract}

Keywords: Development, self-learning, open-ended problem, creativity

\section{INTRODUCTION}

The improvement of education quality is aimed at people who graduate from education departments, including higher education departments, to enable them to compete in all aspects of life based on cognitive or affective (character and personality) skills. Thus, it is natural for tertiary education to provide supporting infrastructure and facilities for students to explore their self-potential and to firm up their personalities, such as self-reliance and creativity. In mathematics learning, students need many adaptations before mastering advanced cognitive skills [1]. Learning styles affect the students' learning process, so that the knowledge of thereof can be used as a consideration in designing learning [2-4].

One of the attitudes that have to be owned by students in higher education is independent learning. The learning characteristics in tertiary education make students plan, do, even evaluate independently their own learning processes. According to Wedemeyer, independent learning needs to be passed on to students in order to make them have responsibilities in arranging and managing themselves in developing learning abilities based on their own will [5]. Those attitudes need to be owned by students, because those are the characteristics of maturity in learning. Enhancement and quality of education and educational empowerment is a system and a programme that is constantly promoted by the government and the group, since great quality education can enhance human resources that have sufficient learning [6].

Panen states that independent learning does not mean that students learn by themselves [7]. It does not mean that there is an effort to isolate students from their friends and teachers. The most important thing in the process of independent learning is that students acquire ability and skill improvement without any help from others, so that eventually students do not rely on teachers, instructors, friends or others in learning. Independent students will be able to look for the learning resources that they need [5]. It is suggested that calculus teaching should be arranged well, so that goals in the cognitive area are met, and also that targets in affective and psychomotor area are reached.

The difficulty that is often found by students in calculus classes is understanding the material and solving problems, i.e. starting from the process of understanding the concepts and principles, such as from definitions and theorems to concept and principle implementation in solving a given problem. Students still have difficulty in solving problems quickly and accurately by themselves. This is because students' strategy in learning has not developed optimally yet or, in other words, their independence and creativity in learning has not developed yet. Therefore, to maximise the calculus learning of the students that are supported by students' creativity in solving calculus problems and placing educators as 
facilitators in learning calculus, a learning model based on an open-closed problem and independent learning needs to be implemented. The main purpose of this research is to produce an independent learning model based on open-ended questions (PMBST - accronym form Indonesian) to improve students' creativity in calculus learning in a valid and practical way.

\section{METHODS}

In line with the purpose of this research to produce the PMBST model to improve students' creativity in calculus learning, this research is categorised as research and development. The main product of this research is the PMBST model, but as a requirement to assess the quality (validity and hypothesis practice) of the model, supporting instruments in the form of a model assessment sheet and validation should also be developed.

The development of the PMBST model follows development phases of a general education problem model, which has been described by Plomp, and that consists of four phases as indicated below [8][9]. However, it has been modified by inserting elements of the learning model illustrated by Joice et al [10], which covers: a) syntax; b) social system; c) reaction principle; d) supporting system; and e) instructional and additional impact. Meanwhile, to assess the quality of the model, the quality criteria of certain products are assessed as indicated by Nieven [11], which covers validity and practical hypothesis. The model development of Plomp [8][9] is shown below:

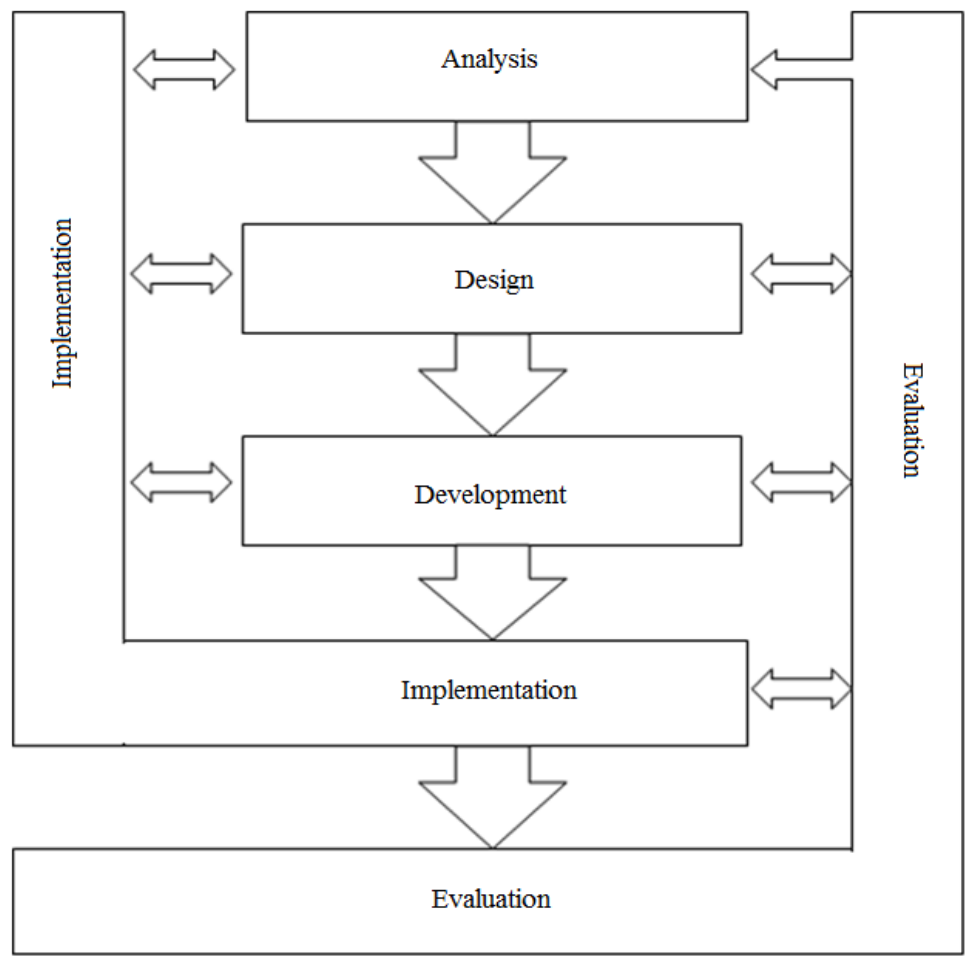

Figure 1: Verhagen’s 2000 model, building on that of Plomp, 1982 [12][13].

The subjects of the PMBST model in this research are the postgraduate students of the Mathematics Department at Universitas Negeri Makassar, who have finished or are learning the calculus subject. The instrument which has been developed for supporting the PMBST model development covers: a) an assessment sheet of the PMBST model; and b) a validation form of the PMBST model assessment sheet.

The activities that are undertaken in the process of analysing the data validity of the PMBST model are as follows:

1. Recapitulate the results of the experts and practitioners.

2. Look for the mean of score of experts and practitioners' assessment results for each criterion, each aspect, and the whole assessment aspect.

3. Determine the validity category of each criterion or aspect or the whole aspect by categorising it a: very valid $(3.5 \leq 4)$, valid $(2,5<3.5)$, fairly valid $(1.5<2.5)$ and invalid $(0<1.5)$.

4. The criteria that were used to decide that the PMBST model has a sufficient degree of validity are: a) the mean score of assessment for the whole minimum aspect is in an adequately valid category; and b) mean score for each aspect should at least be in the valid category.

\section{RESULTS AND DISCUSSION}

The analysis of the PMBST model's assessment results by two experts in mathematics education in regard to model feasibility in perspective theory can be explained below. 
Table 1: Results of the analysis of the PMBST model's assessment.

\begin{tabular}{|c|c|}
\hline Indicator/aspect & Mean of score \\
\hline Rationality & 3.9 \\
\hline Supporting theory & 4.0 \\
\hline Syntax & 3.9 \\
\hline Social system & 4.0 \\
\hline Reaction principle & 4.0 \\
\hline Supporting system & 3.9 \\
\hline Instructional and additional & 4.0 \\
\hline Learning implementation & 3.9 \\
\hline Learning environment and task management & 3.5 \\
\hline Overall & 3.9 \\
\hline
\end{tabular}

Based on Table 1, the analysis of the PMBST model's assessment result by two experts in mathematics education in regard to the feasibility of this model from a practical perspective (practical model) shows that the overall results of the expert assessment about the practicality of the PMBST model is very valid $(\mathrm{M}=3.9)$. Similar to the practicality of each aspect of the PMBST model, which is assessed, the feasibility of its practice, it can be seen that there are five aspects (syntax, social system, reaction principle, supporting system and learning implementation), which are stated as being very valid with $\mathrm{M}=4.0$ and only aspect i.e. learning environment and management system is also stated as very valid with $\mathrm{M}=3.5$.

The PMBST model that has been developed has a high level of theoretical rationality, which is indicated by experts' assessment that are in the category of very valid. These results are in line with the theoretical discussion that: 1 ) students who have previously taken calculus matriculation have an understanding of the concepts and basic principles of calculus and they have been classified as adults who have to be taught with an andragogy approach; 2) the main approach of the calculus matriculation subject for these postgraduate students in the Mathematics Department of Universitas Negeri Makassar is no longer based on an understanding of concepts and basic principles of calculus, but on development aspects of high order thinking, such as the ability to think creatively that is placed at the highest level in the dimension of the cognitive process of the revision result of Bloom's Taxonomy by Anderson and Krathwohl [14]; and 3) one of the places that is appropriate for developing creative thinking abilities of students in calculus is by giving more training to them to solve problems or open-ended problems. All of those three theoretical rationalities are highly relevant as part of the important theoretical basis for developing the PMBST model.

The components of the PMBST model comprise five elements, namely: 1) syntax; 2) social system; 3) reaction principles; 4) supporting system; and 5) instructional/additional impact in the aspect of completeness, clarity, relevance of content, practicality, and linkages among components of the PMBST model are stated as very valid by experts/practitioners.

The PMBST syntax model, which consists of five phases, namely: 1) delivering learning goals and motivation; 2) provisioning individuals/groups; 3) working on open-ended questions in a group; 4) presentation and feedback of group work; and 5) evaluation and reward with the emphasis on students' independence in learning calculus. In the second phase, students independently review their understanding about the concepts and basic principles of calculus, which has an impact on the improvement of their understanding of calculus subject material, while in the third phase, students independently practice open-ended questions, which impacts on the improvement of students' creativity in resolving calculus problems. The social system that is adopted in PMBST models is multidirectional interaction, but it has a professor as the facilitator and students are actively independent in understanding the material and even completing/finishing open-ended questions.

\section{CONCLUSIONS}

Based on the results of the research and discussion, the conclusion of this study is formulated as follows:

1. The PMBST model development is carried out by referring to Plomp's five steps/stages of development of the PMBST model, namely:

a) the preliminary investigation phase in which in theoretical and empirical rationality, supportive learning theory, and the analysis of initial condition of the calculus class as a fundamental basis to develop the PMBST model can be successfully formulated;

b) the design phase, in which the PMBST model book has been designed in the following format: introduction, theoretical rationality, empirical rationality, supporting theories, components of the model, implementation guidance of model and the references;

c) the realisation/construction phase in which, at this stage, an early draft of the PMBST model book has been successfully created; 
d) the test, evaluation and revision phase, in which validation and analysis of validation results have been carried out, as well as improvements of the PMBST model book have been made based on validator's advice;

e) the implementation phase.

2) The PMBST model that has been developed has a high level of theoretical rationality, which is indicated by experts' assessment of what is in the very valid category.

3) The is a supporting theory of the PMBST model consisting of:

a) the theory of constructivism;

b) the theory of cognitive development of Piaget [15];

c) cognitive learning theory from De Block [16];

d) learning to think and learn by Parreren [17];

e) cognitive learning activity arrangements from Gagne, are considered very relevant (very valid) by experts/practitioners.

4) Components of the PMBST model follow the model components according to Joyce et al [10], which consist of five elements, namely:
a) syntax;
b) social system;
c) the principles of reaction;
d) supporting system;
e) instructional/additional impact; completeness, clarity, relevance of content, practicality, and linkages between the PMBST model components are stated as very valid by experts/practitioners.

5) The PMBST model guidelines are outlined in four aspects, namely:
a) task planning;
b) interactive tasks;
c) the learning environment and task management;
d) evaluation; completeness, clarity, relevance of content, practicality and linkages between aspects of the implementation of the PMBST model are considered as very valid by experts/practitioners.

Based on the research conclusion, which states that the PMBST model has already achieved adequate validity, it is advisable to researchers to continue this research in the form of trial implementation of the model by first developing the additional learning device by referring to the PMBST model. Although the process of developing the new PMBST model is limited to assessment by experts and it has not reached the trial process, the PMBST model can now be used by lecturers in teaching calculus to a limited extent.

\section{REFERENCES}

1. Rahman, A. and Ahmar, A.S., Exploration of mathematics problem solving process based on the thinking level of students in junior high school. Inter. J. of Environmental Science Educ., 11, 14, 7278-7285 (2016).

2. Rahman, A., Ahmar, A.S. and Rusli, The influence of cooperative learning models on learning outcomes based on students’ learning styles. World Trans. on Engng. and Technol. Educ., 14, 3, 425-430 (2016).

3. Rahman, A. and Ahmar, A.S., Relationship between learning styles and learning achievement in mathematics based on genders. World Trans. on Engng. and Technol. Educ., 15, 1, $74-77$ (2017).

4. Mulbar, U., Rahman, A. and Ahmar, A.S., Analysis of the ability in mathematical problem-solving based on SOLO taxonomy and cognitive style. World Trans. on Engng. and Technol. Educ., 15, 1, 68-73 (2017).

5. Rusman, Model-model Pembelajaran: Mengembangkan Profesionalisme Guru. (2nd Edn), Jakarta: Raja Grafindo Persada (2014) (in Indonesian).

6. Takdirmin, P.B., Upu, H. and Dirawan, G.D., Analysis understanding of the smp students build concept and principles of flat in math, Man in India, 95, 3, 821-827 (2015).

7. Panen, P. and Sekarwinahyu, Belajar mandiri dalam mengajar di perguruan tinggi. Program Applied Approach, 2. Jakarta: PAU-PPAI, Universitas Terbuka (1997) (in Indonesian).

8. Plomp, T., An introduction to educational design research. Proc. the Seminar Conducted at the East China Normal University, Shanghai: SLO-Netherlands Institute for Curriculum Development, 9-36 (2007).

9. Plomp, T., Educational and Training System Design. Enschede University Twente (1997).

10. Joyce, B.R., Weil, M. and Showers, B., Models of Teaching. (9th Edn), Cambridge: Pearson Addison Wesley (2014).

11. Nieveen, N., Prototyping to Reach Product Quality. In: van den Akker, J., Branch, R.M., Gustafson, K., Nieveen, N. and T. Plomp, T. (Eds), Design Approaches and Tools in Education and Training. Dordrecht: Springer Netherlands, 125-135 (1999).

12. McKenney, S. and Visscher-Voerman, I., Formal education of curriculum and instructional designers, Educ. Designer, 2, 6 (2013). 
13. Ahmar, A.S. and Rahman, A., Development of teaching material using an Android. Global J. of Engng. Educ., 19, 1, 72-76 (2017).

14. Anderson, L.W. and Krathwohl, D.R., A Taxonomy for Learning, Teaching, and Assessing: A Revision of Bloom's Taxonomy of Educational Objectives. Boston: Allyn \& Bacon (2001).

15. Piaget, J., Piaget's theory of cognitive development, Child. Cogn. Dev. Essent. Readings, 33-47 (2000).

16. De Block, A., Taxonomie van Leerdoelen (Taxonomy of Learning Objectives). Antwerp-Amsterdam: Standard Academic Publishers (1975).

17. Van Parreren, C.F., A viewpoint in theory and experimentation on human learning and thinking, Acta Psychol. (Amst), 10, 351-380, (1954).

\section{BIOGRAPHIES}

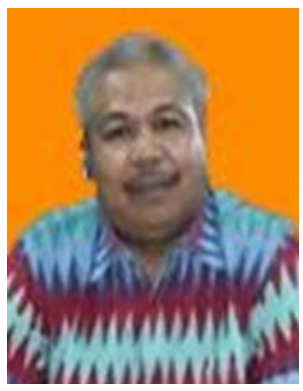

Nurdin Arsyad is a professor in the Department of Mathematics of the Faculty of Mathematics and Natural Sciences at Universitas Negeri Makassar, Indonesia. He graduated with a Bachelor's degree in mathematics education at Universitas Negeri Makassar, Indonesia. He received his Master's degree (MPd) and doctoral degree (Dr) in mathematics education at Universitas Negeri Surabaya, Indonesia. He became a professor of Mathematics Education at Universitas Negeri Makassar in 2007 and he is Head of postgraduate studies in the Mathematics Department at Universitas Negeri Makassar, Indonesia.

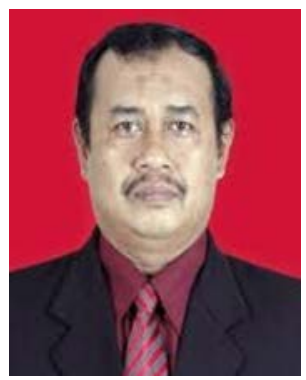

Abdul Rahman is a professor in the Department of Mathematics, Faculty of Mathematics and Natural Sciences, Universitas Negeri Makassar, Indonesia. He graduated with a Bachelor's degree in mathematics education at Universitas Negeri Makassar, Indonesia, in 1986. He received his Master's degree (MPd) in mathematics education at Universitas Negeri Surabaya, Indonesia, in 1997, and his doctoral degree (Dr) in mathematics education from Universitas Negeri Surabaya, Indonesia, in 2006. He became a professor of mathematics education at Universitas Negeri Makassar in 2014. Presently, he is Dean of the Faculty of Mathematics and Natural Sciences at Universitas Negeri Makassar, Indonesia.

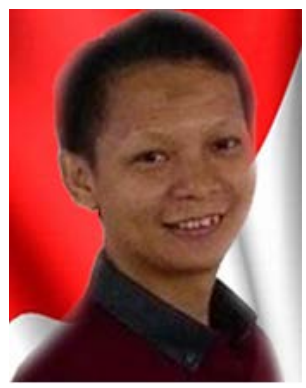

Ansari Saleh Ahmar is a lecturer in the Department of Statistics of the Faculty of Mathematics and Natural Sciences at Universitas Negeri Makassar, Indonesia. He graduated with a Bachelor's degree in mathematics at Universitas Negeri Makassar, Indonesia, in 2009. He received his Master's degree (MSc) in mathematics, specialising in statistics at Universitas Gadjah Mada, Indonesia, in 2013. Apart from being a lecturer, he is also a member of the IT Team in the ICT Centre, Universitas Negeri Makassar. Ansari has also reviewed several articles on mathematics, statistics and IT. 